\title{
Economic and Technical Feasibility of Upcountry Vegetable Production in Halmillewa ( $\left(\mathrm{LL}_{1 \mathrm{a}}\right)$
}

\author{
D.G.K.P. Wijerathne ${ }^{*}$ and W.A.P. Weerakkody ${ }^{1}$ \\ Postgraduate Institution of Agriculture \\ University of Peradeniya \\ Sri Lanka
}

\begin{abstract}
Market supply of upcountry vegetables suffers heavily during prolonged rainy periods due to crop failures in the main centers of production. The best resolution might be the alternative production regions in relatively dry areas. North Central and North Western dry/intermediate regions during Yala season are highly potential for this task. Therefore the study assessed the technology and economy of upcountry vegetable production in Halmilewa Grama Niladari Division that belongs to agro-ecological region $I L_{1 a}$ with the aim of assessing its production potential. Primary and secondary data on crops, varieties, agronomy and marketing were collected, tabulated and examined statistically to understand the standards, technological strength and economy of vegetable production in Halmillewa.

Significant differences could be seen in extent of cultivation, selection of crops and agronomic practices within the farming community. Income generation also varied with the selected vegetable crop because cost of cultivation, yield generation and farmgate prizes were different. Most preferred upcountry vegetable by the farmers in Halmilewa Agrarian Services Division is cabbage despite the fact that Knol khol is giving the lowest breakeven yield and the highest gross income. Chemical (synthetic) pesticide application is relatively high in both knol khol and cabbage. Lack of proper advisory support was found to be one of the major limiting factors of the economic and environmental sustainability of this very specific rice based vegetable based cropping system practiced in a highly potential farming region.
\end{abstract}

Keywords: Agro-chemicals, farmer income, marketing, Up-country, Vegetable

\section{INTRODUCTION}

Sri Lankan consumer market for vegetables is usually flooded with fresh vegetables. Market supply of fresh vegetables in Sri Lanka is affected by prolonged heavy rains seasonally, causing substantial price hikes (Suriyagoda et al., 2012). More often rainfall caused crop failures and yield loses occur in the central highlands which supplies nearly $70 \%$ of the upcountry vegetables to the local market (HARTI, 2015). Therefore, promotion of upcountry vegetable cultivation in mid country and low country areas particularly in the Yala season has been identified as a national priority in agriculture and an essential component in national food security in vegetables (Ministry of Agriculture, 2010). North, Northwestern and Central parts of dry zone which covers agro-ecological zones, $\mathrm{DL}_{1-3}$ and $\mathrm{IL}_{1}$ are highly potential regions in this regard.

\footnotetext{
1 Department of Crop Science, Faculty of Agriculture, University of Peradeniya, Peradeniya

* Corresponding Author: dg.kovida.pw@gmail.com
} 
Halmillewa is one of the twelve Grama Niladari (GN) Divisions, operated by the Madahapola Agrarian Services Center in Kurunegala District. It belongs to agro-ecological region, low country Intermediate zone $\left(\mathrm{IL}_{1 \mathrm{a}}\right)$. Halmillewa hosts 400 farm families, who makes their living predominantly on rice based vegetable cultivation.

The region is fed by Hakwatuna Oya major irrigation scheme. Mostly paddy (rice) farming is limited to the Maha (rainy) season while vegetables are cultivated in the Yala season as well as inter-seasonal gaps with supplementary irrigation. Some farmers include some other vegetable or field crops such as onion, chilli, pumpkin, okra, ginger etc. into their cropping pattern. Therefore this study was carried out basically to assess the economic and environmental sustainability of cultivating popular upcountry vegetables in Halmillewa, mainly based on farmer perceptions.

\section{MATERIALS AND METHODS}

Out of several villages belong to Halmillewa grama niladari (GN) Division, Pansiyagama village having GPS coordinates; $7^{\circ} 44^{\prime} 6.54 " \mathrm{~N}$ (Latitude) and $80^{\circ} 29^{\prime} 48.63 " \mathrm{E}$ (Longitude) was selected for the study. It belongs to agro-ecological region of $\mathrm{IL}_{1 \mathrm{a}}$ where the elevation category is less than $300 \mathrm{~m}$, the annual rainfall category is $1750-2500 \mathrm{~mm}$ and the soil type is Red Yellow Podsolic soil. Usually $\mathrm{IL}_{1 \mathrm{a}}$ is having warm days and nights all throughout the year where the maximum and minimum temperature ranges are $28-38{ }^{\circ} \mathrm{C}$ and $18-28{ }^{\circ} \mathrm{C}$, respectively (NRMC, 2016).

Halmellawe GN Divison covers the villages, Pansiyagama, Banbaragala yaya, Irudeni yaya , Makulpotha, Mahapitiya, Ulpathgama and Dummeya. For the farmer survey, 50 farm families (out of 400) were selected based on Random Stratified Sampling Technique and, the survey was conducted during January to October in 2015, covering their farm practices in both Yala and Maha seasons of cultivation. Primary data collection was done using a structured questionnaire, and interviewing individual farmers was followed by focus group discussions and direct field observations to ensure the validity of data. This was supplemented with secondary data that were also collected by searching through published and unpublished sources of information.

Categorical data were tabulated and subjected to analysis through the Chi-square procedure while yield and income data were analysed through ANOVA procedure. For economic analysis, the following indicators were developed;

(a) Profit including input cost $=$ Gross return (including input cost) - Cost of cultivation

(b) Per unit cost $=$ Cost of cultivation (including input cost) $/$ Average yield

(c) Break even yield $=$ Cost of cultivation (including input cost) $/$ Farmgate price

\section{RESULTS AND DISCUSSION}

\section{General characteristics of the farming community}

A significant group of farmers (40\%) have 1.6-2.0 ac. (0.7-0.9 ha) of own lands for cultivation. Knol khol, beet, cabbage and radish were the most popular vegetable crops among them. Appproximately 50\% farmers cultivated 0.5 ac of land extent for each crop. 
According to secondary data and farmers comments, $56 \%$ of farmers had a more than 30 years of cultivation history. The average size of a farm family was 4-5 members (as reported by nearly $74 \%$ farm families).

\section{Farmer perceptions towards extension}

Farmer perception on the effectiveness of advisory services are driven towards the private sector (i.e. sales representatives and agrochemical dealers) (84\%) compared to state sector (Agricultural Instructors) (16\%). This is very much comparable with vegetable based cropping systems in elsewhere (i.e. commercial year-round systems in Nuwara eliya and Kalpitiya) (Suriyagoda et al., 2012). Hence, their choice of crops, varieties, general field practices, brand and type of agrochemicals and their application dosages are solely based on either experience or the advisory received through non-formal communications.

\section{Crop and variety selection}

Most farmers' first choice was cabbage while preference for the remaining crops were almost the same (Table 1). However this is not well explained by income data as the case of some other reports on vegetable farming. Meanwhile, their variety selection was limited to availability of seeds at the beginning of the season. They were not aware of the recommended varieties (by Department of Agriculture) and were not educated on either the value of recommended varieties or the production risks of cultivation unknown varieties. However they complained about low rate of germination of particularly the cabbage and beet seeds.

Table 1 Crop selection and frequency of field practices by vegetable farmers (\%)

\begin{tabular}{|c|c|c|c|c|c|}
\hline Crop & Preference & Cultural Practice & Always & Sometimes & Rarely \\
\hline Knol khol & 46 & - Crop rotation & 88 & 10 & 02 \\
\hline Beet & 42 & - Sterilization & & & \\
\hline Radish & 44 & nursery & 74 & 24 & 95 \\
\hline Cabbage & 84 & - Removal of residue & 00 & 05 & 02 \\
\hline
\end{tabular}

\section{Cultural practices of sample farmers}

Farmers were very keen on some of the recommended cultural practices such as crop rotation and sterilization of nursery medium. However, some of the practices such as removal of crop residues at the end of the season were rarely practiced (Table 1).

\section{Use of agrochemicals}

All farmers used triple super phosphate (TSP) as a basal dressing, following the fertilizer recommendations. However most farmers were used to apply commercial fertilizer mixtures, particularly granular fertilizers (i.e. Topcrop ${ }^{\circledR}$ ) in two splits during the season. In addition, they applied calcium containing commercial fertilizers (i.e. Calmax ${ }^{\circledR}$ ). Very few farmers applied foliar (liquid) fertilizers for their crops. Most common method of fertilizer application was manual broadcasting in the form of granules or powders.

Meanwhile the average number of pesticide tanks applied was 14.5 per ha. The highest chemical (synthetic) pesticide use was found in cabbage (487 L/ha) and Knol khol (362 
$\mathrm{L} / \mathrm{ha}$ ) cultivations while the lowest was found in radish $(230 \mathrm{~L} / \mathrm{ha})$ and beet (155 L/ha) cultivations. Assuming correct dilution rate radish and beet cultivations did not exceed the recommended rate of application but knol khol and cabbage farmers seems to apply 3 - 4 times higher volume of application (Pest Rec., 2010).

\section{Farmgate price distribution}

On average, vegetables receive the highest farmgate prices in April and November coinciding with peak rainfall data (HARTI, 2015). As shown in Table 2, Knol khol receives the highest offers (Rs. 100) during these months while other Cruceferaceae crops receive relatively lower offers (Rs. 45 - 65). Vegetable farmers were at disadvantage due to price fluctuation mostly in the months of March and May. Price fluctuations for Knol khol was severe (within Rs. 25 - 100) compared to other vegetable crops. Meanwhile the corresponding average wholesale prices during the same period (June - August, 2015) significantly correlate $(\mathrm{r}=0.82)$ with the farmgate price data (collected from farmers).

Table 2 Fluctuation of farmgate prices (Rs)

\begin{tabular}{lccc}
\hline Crop & Minimum & Maximum & Average* \\
\hline Knol khol & 25 & 100 & 60 \\
Beet & 20 & 65 & 90 \\
Radish & 15 & 50 & 36 \\
Cabbage & 35 & 45 & 33 \\
\hline *Source: HARTI, 2016 & & &
\end{tabular}

\section{Income generation}

Gross Income: The gross income generation from different crops under variable land holdings (cultivation extents) is shown in Figure 1. Knol khol and radish farming resulted a dramatic increase in the gross income when increase the extent of cultivation within $0.25-$ 1.0 ac range. Eventhough a similar rate of increase has been shown by the other popular vegetables, beet and cabbage when increase from 0.25 ac to 0.5 ac. Gross income generation in response to further increase in extent of cultivation of beet and cabbage were found to be lagging, probably due to lack of adequate samples. 


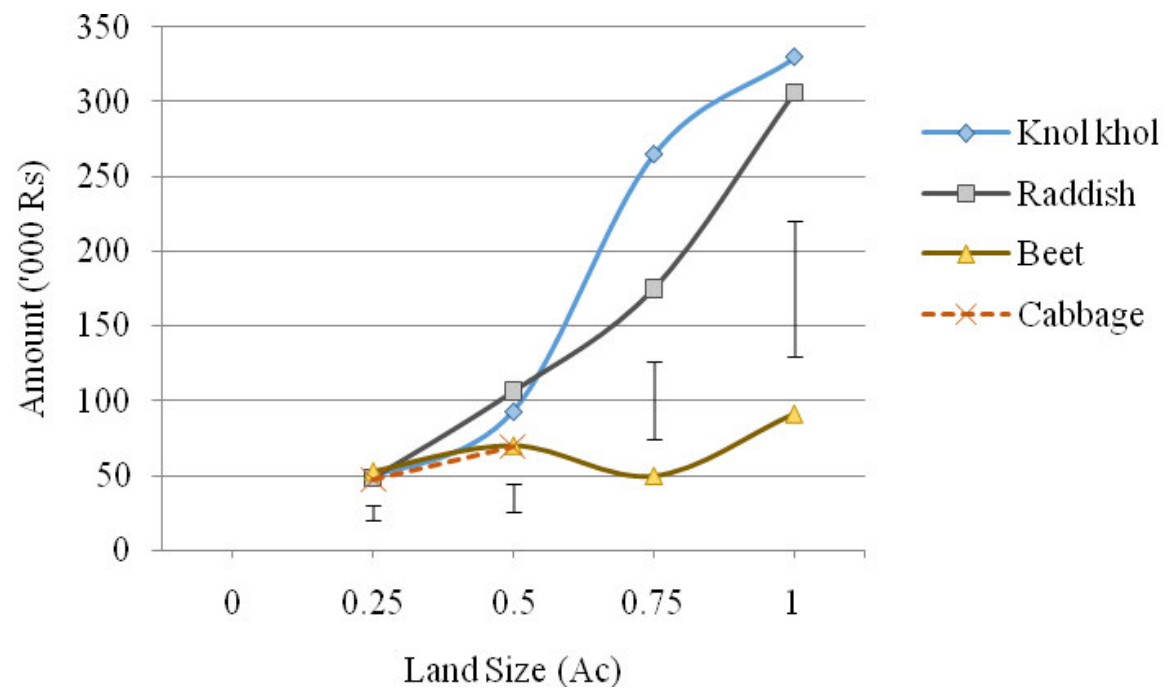

Fig 1. Gross income distribution of vegetable crops when increase the extent ocultivation

(LSD between mean income of crops at $\mathrm{p}=0.05$ are indicated in error bars)

\section{Breakeven yield distribution:}

Breakeven yield (the yield required just to cover the cost of cultivation) was lowest at the lowest extent of cultivation but gradually increased non-linearly with the increasing size of landholding (Figure 2). Knol khol was found to be the lowest in breakeven yield in the full range of land holdings while cabbage also showed similar results at the $0.25-0.5$ ac range of cultivation. The two others, radish and beet showed a relatively high breakeven yield. Eventhough gross income is lower, cabbage must be having a low cost of cultivation (high net profit, compared to others) to be more popular among farmers, as discussed earlier in the section (Table 1). 


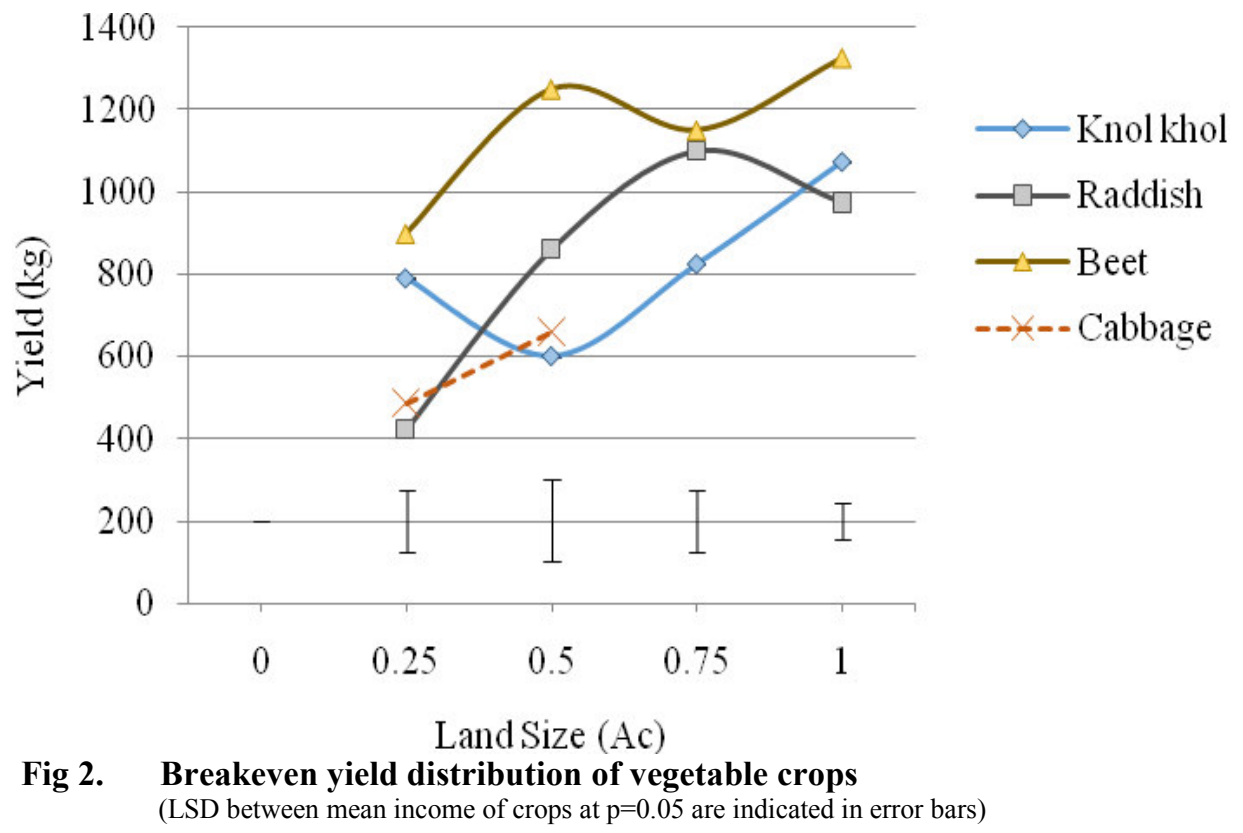

\section{Conclusions}

Most preferred upcountry vegetable by the farmers in Halmilewa Agrarian Services Division is cabbage despite the fact that Knol khol is giving the lowest breakeven yield and highest gross income. Chemical (synthetic) pesticide application is relatively high in both knol khol and cabbage. Lack of proper advisory support was found to be a limiting factor of the economic and environmental sustainability of this very specific rice based vegetable cropping system practiced in a highly potential farming region.

\section{References}

HARTI (2015). Monthly Food Commodities Buletin, Hector Kobbakaduwa Agrarian Research and Training Institute, Wijerama Mawatha, Colombo 07, Sri Lanka. Available at:http://www.harti.gov.lk/images/download/market_information/monthly_price_list/decemb er_2015.pdf

Ministry of Agriculture (2010). Five year plan of the Ministry of Agriculture-2010, Ministry of Agriculture and Mahaweli Developments, Sethsiripaya, Battaramulla.

NRMC (2016). Unpublished Report, Natural Resource Management Center, 52 Sarasvi Mawatha, Peradeniya.

Pest Rec. (2010). Pesticide Recommendations, Department of Agriculture Press, Gannoruwa, Peradeniya.

Sooriyagoda, L.D.B., Ranil, R.H.G., Dissanayake, S. and Weerakkody, W.A.P. (2012). Sustainability of intensive vegetable farming in the upcountry region of Sri Lanka: A situation assessment. Chronica Hort. 52(4), 14-17. 